\title{
A presença do cotidiano durante a ditadura civil-militar argentina (1976-1983): a perspectiva infantil no filme Kamchatka (2002)
}

\author{
The presence of everyday life during the Argentine civil-military dictatorship (1976- \\ 1983): the child's perspective in the film Kamchatka (2002)
}

Ygor Pires Monteiro

Doutorando, Universidade do Estado do Rio de Janeiro ygor_pires01@hotmail.com

Resumo: $\mathrm{O}$ artigo analisa o filme argentino Kamchatka (2002) a partir de um diálogo com o trabalho "O mito da sociedade como vítima: sociedades pós-ditatoriais em face de seu passado na Europa e na América Latina" de Bruno Groppo. No enredo do filme, o protagonista é um menino de 10 anos, cuja vida é alterada poucos dias após o golpe de Estado de 1976 na Argentina por conta da militância política dos pais. Como a obra se debruça sobre o cotidiano da personagem principal, é possível pensar como o cinema contribui para repensar memórias dicotômicas construídas em torno dos comportamentos sociais durante a ditadura civil-militar, nomeadas por Groppo como o "mito da sociedade resistente" e o "mito da sociedade vítima inocente".

Palavras-chave: Cinema; Filmes de temática histórica; Ditadura civil-militar argentina.

\begin{abstract}
The article analyzes the argentine film Kamchatka (2002) from a dialogue with Bruno Groppo's work "The myth of society as a victim: post-dictatorial societies in the face of its past in Europe and Latin America". In the film's plot, the protagonist is a 10-year-old boy, whose life is changed a few days after the 1976 coup d'état in Argentina due to the political militancy of his parents. As the work focuses on the daily life of the main character, it is possible to think about how cinema contributes to rethinking dichotomous memories built around social behaviors during the civilmilitary dictatorship, named by Groppo as the "myth of resistant society" and the "myth of innocent victim society".
\end{abstract}

Keywords: Movies; Historical-themed films; Argentine civil-military dictatorship. 


\section{Memórias controversas sobre o período autoritário}

De tempos em tempos, a velha máxima de que o trabalho de análise e interpretação do passado dos historiadores é movido por anseios e questionamentos do presente se torna mais patente. Em certos contextos históricos, temas ressurgem com uma potência ainda maior impulsionada por polêmicas, controvérsias e discussões acaloradas da atualidade. Essas temáticas podem ser envolvidas por aspectos "quentes" do tempo presente, especialmente conflitos sociais e políticos que resgatam outros períodos históricos. Se as questões forem sensíveis para a sociedade, a interação entre passado e presente ganha contornos ainda mais pulsantes porque afetam de maneira significativa os sujeitos históricos

Como nosso tempo presente é o Brasil e a segunda década do século XXI, podemos observar o espaço público para perceber como a ditadura civil-militar vem sendo recuperada na dimensão do negacionismo histórico. Algumas manifestações acontecem ao redor do país desde 2013 pedindo intervenção militar no governo; o então deputado federal Jair Bolsonaro homenageou o torturador Carlos Brilhante Ustra na votação do impeachment da presidente Dilma Rousseff em 2016; e durante o governo do presidente Jair Bolsonaro desde 2018, episódios relacionados ao Ato Institucional n5 (AI-5) e ao fechamento de instituições democráticas ocorreram ${ }^{1}$.

O conteúdo autoritário dessas ações pode nos indicar como a ditadura civil-militar brasileira segue sendo um tema mal enfrentado em sociedade. Se nos governos da Nova República imediatamente posteriores ao regime ditatorial, havia um cenário de esquecimento relacionado à Lei da Anistia, os últimos anos têm demonstrado ocorrer uma apropriação negacionista da ditadura por certos setores sociais e políticos. Entre as possibilidades de reflexão sobre a presença do passado autoritário no presente, está a história comparada, por exemplo com a Argentina, já que nossos vizinhos possuem outra experiência histórica diante de seu passado antidemocrático.

Diferentemente do caso brasileiro, marcado pela retomada de discursos acerca do perigo comunista e pela negação do caráter violento da ditadura, a Argentina tem dado exemplos de um enfrentamento mais sólido de seu passado. Espaços anteriormente

\footnotetext{
${ }^{1}$ Podemos fazer, através da observação empírica dos acontecimentos recentes no Brasil e amplamente noticiados, um recorte inacabado que se inicia nas Jornadas de Junho de 2013 (quando nas diversas manifestações ocorridas em cidades brasileiras, iniciadas por conta do aumento das tarifas de transporte público, alguns manifestantes defenderam intervenção militar) e segue avançando nos anos posteriores até o ano de escrita desse trabalho.
} 
usados como centros de repressão foram reapropriados como lugares de memória; as manifestações de organizações de direitos humanos lutam pela resolução do problema dos desaparecidos políticos; a efeméride do golpe de Estado de 1976 não tem caráter celebrativo e sim um símbolo de embate contra o esquecimento. Essas e outras situações demonstram como os comportamentos dominantes na sociedade argentina têm sido de repúdio e combate ao período ditatorial e seus desdobramentos ${ }^{2}$.

Então, quando nos referimos às ditaduras civil-militar na América Latina, estamos diante de um tema que pertence a um passado recente que não passa, ou seja, ainda impacta diferentes sociedades atuais que precisam lidar com as "heranças" deixadas. Os impactos se fazem presentes, sobretudo nos debates acerca das ações repressivas que alcançam processos de reparação das vítimas e julgamento dos indivíduos envolvidos nas violações aos direitos humanos. Quanto a isso, o atual presidente argentino Alberto Fernández já se moveu no sentido de avaliar as possibilidades de criar uma lei que criminalize negacionistas da ditadura e de avançar nos processos jurídicos punitivos para setores civis participantes e/ou cúmplices dos aparatos de repressão.

Embora possa parecer que tais questões ressoem mais nos governos ou nos movimentos sociais, o papel dos historiadores também assume uma importância específica. Atravessado por aspectos sensíveis, como violência e autoritarismo, o campo da história do tempo presente vem se construindo na América Latina com as ditaduras civil-militar como eixo importante e a necessidade da atuação pública de pesquisadores e estudiosos. Como alerta René Rémond (1996: 209), a história do tempo presente não seria apenas uma suposta objetividade racionalista que levaria os historiadores a simplesmente observarem fatos contemporâneos, já que nós também contribuímos na sua construção e somos afetados por eles a curto e médio prazo.

É bem verdade que o historiador francês tem como referência o panorama de seu país, onde os profissionais da história são alçados a especialistas para os discursos sobre o passado e correm o risco de se apropriarem da história como se fosse de sua propriedade (RÉMOND, 1996: 208). Já em algumas regiões da América Latina, o lugar social do historiador parece estar no extremo oposto: uma crescente desconfiança que descredibiliza o método histórico e as operações científicas para produzir conhecimento

\footnotetext{
${ }^{2}$ Da mesma forma que no caso do Brasil, os diversos exemplos de como a sociedade argentina vem lidando nos últimos anos com sua ditadura civil-militar podem ser apreendidos a partir do amplo noticiário que vivenciamos a cada dia.
} 
(notadamente, é algo que se percebe no Brasil quando pesquisadores são diminuídos como figuras supostamente propagandistas de ideias políticas à esquerda).

Para fortalecer o ponto acima, podemos pensar como a dimensão temporal da história do tempo presente enfatiza o peso da memória e da experiência no curso da história. Como aponta Luisa Passerini (1996: 213-214), o tempo não é um fluxo contínuo no qual o presente seria uma lacuna pressionada pelos legados do passado e pelas expectativas do futuro, mas um campo de forças no qual sujeitos pensam, vivenciam experiências e constroem significados. Assim, podemos assumir como a história do tempo presente se relaciona com a perspectiva de que o historiador também é esse indivíduo que age no espaço público com base nos seus estudos, que entrelaçam passado e presente com vistas a um futuro possível.

Portanto, quando o historiador é contemporâneo de seu objeto de estudo, alguns cuidados são necessários. A história do tempo presente pode examinar memórias, desde que tenha a preocupação teórico-metodológica de que constantemente se debruça sobre as múltiplas e conflitantes formas de rememoração e usos do passado (CHARTIER, 1996: 216). Além disso, por mais que a história atualmente se depare com distintas narrativas que se voltam para o passado (memórias, testemunhos, obras de arte...), é o trabalho dos historiadores que possui uma ambição de verdade capaz de produzir conhecimento. E este conhecimento tem uma elaboração meticulosa que lhe permite superar os limites subjetivos e parciais de outras formas de reconstrução do passado.

Não se quer dizer com isso que as memórias não são relevantes para os estudos históricos, afinal a América Latina e, em particular, a Argentina, contaram com as mobilizações de associações de vítimas da ditadura e de defesa dos direitos humanos para lutar contra tentativas de esquecimento e de silêncio no que se refere às memórias traumáticas do passado recente (GROPPO, 2015: 39). Então, apesar de reconhecermos como as rememorações de sujeitos históricos são valiosas para a compreensão do período autoritário, a memória não se confunde com a história nem ocupa seu lugar como produção de saberes. Algumas armadilhas podem surgir dessa confusão e se considerarmos apenas os significados que os testemunhos atribuem ao passado.

Como Bruno Groppo sustentou em seu trabalho acerca da relação de sociedades europeias e latinoamericanas com experiências ditatoriais, alguns mitos podem ser criados em razão da dificuldade de enfrentar criticamente passados dolorosos. Nessas ocasiões, sociedades recém-saídas de ditaduras ou de outros fenômenos trágicos sofrem com a tentação de criar narrativas que deformam ou ocultam traços da realidade para 
evitar choques desgastantes com traumas, dores ou sofrimentos coletivos (GROPPO, 2015: 41-42). Assim, muitas vezes nos deparamos com versões maniqueístas ou simplificadoras que dificultam a compreensão de processos históricos complexos.

Tais maniqueísmos e simplificações podem ser resultantes de trabalhos de memória e de esquecimento. Como argumenta Groppo, poderes públicos podem tomar medidas que orientam a construção de determinadas interpretações do passado, moldando-as com uma memória pública e políticas de esquecimento (GROPPO, 2015: 46-47). Com operações assim, cria-se um sentido para o passado (que dispensaria a necessidade de lidar com traumas e responsabilidades) e projeta-se um futuro (que dispensaria maiores preocupações com os esforços para evitar a repetição de momentos violentos, autoritários e desagradáveis para a sociedade).

Sendo mais específico, o historiador francês nomeia dois mitos perigosos que surgem da dificuldade de enfrentar verdades dolorosas durante a redemocratização: a sociedade vítima inocente e a sociedade integralmente resistente (GROPPO, 2015: 4243). No primeiro, o relatório da Comissão Nacional sobre o Desaparecimento de Pessoas (CONADEP) descrevia a sociedade argentina como refém da violência do terrorismo do Estado e dos movimentos guerrilheiros. No segundo, a ditadura teria sido imposta e mantida exclusivamente pelo terror e pela força porque a sociedade teria resistido desde o princípio ao governo de exceção.

Os dois exemplos nos servem para entender o que Maria Helena Capelato nomeia como excesso de memória (CAPELATO, 2006: 73). Em diálogo com outros estudiosos, como Beatriz Sarlo, Paul Ricoeur e Elizabeth Jelin, a autora examina os problemas da multiplicação dos discursos memorialísticos na contemporaneidade (livros, exposições fotográficas, filmes, peças teatrais...) sob a ideia de que não basta rememorar o passado. É extremamente necessário refletir conscientemente sobre o passado, elaborando criticamente sentidos importantes para o presente e para o futuro, mas sem atribuir às memórias testemunhais um monopólio de verdade para a reconstrução do passado.

Em nome dos cuidados com os discursos memorialísticos, Maria Helena Capelato demonstra como toda memória precisa ser historicizada para que estudos históricos sobre a ditadura civil-militar argentina e seus desdobramentos até a redemocratização sejam feitos. A partir da varredura pelos contextos de produção de memórias sobre o tema, a historiadora já mostrou como os usos e sentidos do passado recente argentino se transformaram de acordo com períodos históricos (na vigência da ditadura, na transição 
democrática e na atualidade anos depois da redemocratização) e com os personagens em questão (militares, guerrilheiros e parentes das vítimas) (CAPELATO, 2006: 68-69).

Tendo em vista a historicização e o trabalho crítico com as memórias, podemos nos interrogar sobre as potencialidades da análise do filme Kamchatka. O cinema também pode ser compreendido como multiplicador de memórias, já que se trata de uma narrativa capaz de dar significados ao passado através de experiências subjetivas. Do mesmo modo, pode contribuir nos debates a respeito das representações do passado recente. E quando se trata do filme dirigido por Marcelo Piñeyro, pode nos ajudar a refletir como os comportamentos sociais durante a ditadura argentina ultrapassam os mitos de sociedade vítima inocente e sociedade integralmente resistente.

\section{O olhar infantil que se abre para o cotidiano em "Kamchatka"}

Abordar a interface entre cinema e história significa fazer parte de uma considerável jornada de pensamentos e formulações de diversos autores. Desde o pioneirismo de Marc Ferro, o diálogo entre as duas áreas proporcionou a percepção de alguns pontos fundamentais que giram em torno de uma questão central: os filmes de temática histórica produzem representações do passado histórico encenado no enredo e informam sobre as condições do presente que levaram a encenar aquele período histórico. Qualquer que seja a produção cinematográfica, existe um duplo componente temporal que demonstra permite ao cinema ser tanto fonte quanto objeto.

Como fonte histórica, os filmes constroem representações do passado que se diferenciam da forma como a historiografia se debruça sobre períodos históricos já decorridos. Ao longo do percurso dos estudos das relações entre cinema e história, um erro muito comum foi exigir que as narrativas cinematográficas representassem visualmente as conclusões alcançadas pela academia. Essa postura levou à realização de um "jogo dos sete erros", no qual os historiadores simplesmente identificavam as incongruências históricas do filme e desconsideravam o fato de que a arte é produto da visão histórica e sensível dos realizadores sobre o passado.

Com o passar do tempo, esse cenário passou por transformações e o cinema começou a ser considerado segundo as possibilidades, os interesses e as características próprias de sua narrativa (ROSENSTONE, 2010: 232-233). Nesse sentido, é necessário 
examinar não apenas o que se propõem textualmente através da construção do roteiro, mas também da linguagem cinematográfica como um todo. Estamos diante de uma narrativa que cria significados a partir de uma estrutura dramática com invenção, reformulação, condensação e romantização de fatos, personagens e temporalidades, e de uma estética composta por trilha sonora, direção, figurino, efeitos sonoros, montagem...

Já como objeto histórico, os filmes ultrapassam concepções que pensam essas obras somente como reflexos de uma realidade exterior. Ao longo do percurso desenvolvido, as pesquisas historiográficas também concluíram que a análise das imagens se justifica apenas quando estas são consideradas em suas particularidades e não como ilustrações de conhecimentos ou de informações prévias. É nessa dimensão que faz sentido pensar que o cinema é uma construção que se posiciona diante da realidade, a afeta e a reinventa (CAPELATO, 2007: 10). Então, além de fazer parte do contexto histórico, os filmes também ajudam a formar esse contexto.

Dentro de uma abordagem que toma o cinema como agente ativo de interferência na realidade, podemos nos interrogar sobre as potencialidades de atribuir ao cinema o papel de produtor de memórias. As narrativas cinematográficas podem mobilizar leituras sobre o passado enquanto recordam acontecimentos já ocorridos? Essa mobilização pode impulsionar interpretações já construídas sobre o passado ou contribuir para a construção de diferentes usos do passado? As memórias podem ser fruto das experiências pessoais dos realizadores encenadas de forma criativa e artística? Com esses questionamentos podemos colocar em perspectiva o filme Kamchatka, tendo o trabalho de Bruno Groppo como horizonte de debates.

Dirigido por Marcelo Piñeyro e lançado oficialmente em 2002, Kamchatka se passa poucos dias após o golpe de Estado de 1976 que fez iniciar última ditadura civilmilitar na Argentina. Enquanto cidadãos começam a desaparecer e militares cada vez mais são vistos pelas ruas de Buenos Aires, um pai leva a esposa e os dois filhos para uma distante casa nos arredores da capital argentina. Nesse novo cenário, os adultos se dedicam a atividades misteriosas que jamais se revelam claramente, já as crianças tentam se adaptar a uma nova vida, na qual precisaram assumir novas identidades e se manter afastados de familiares e amigos.

Apesar de contar com personagens adultas que têm uma relação mais direta com os fatos históricos da Argentina no fim da década de 1970, a narrativa coloca o protagonismo para o filho mais velho do casal, um menino de dez anos. Tal escolha impacta no que vemos na tela: não a violência do Estado, a resistência de setores da 
oposição ou qualquer outro evento marcante da história do país, mas o desenrolar do cotidiano sob o ponto de vista de uma criança. Trata-se, portanto, de um recorte que nos evoca o alerta de Groppo quanto às complexidades e ambiguidades e de uma realidade povoada por diversas atitudes sociais em tempos autoritários (GROPPO, 2015: 45).

Não estamos afirmando que a ditadura não se faz presente na narrativa. Porém, sua presença é sutil e parece estar quase sempre às margens da cena sem ocupar a preponderância do espaço cênico. É o que se vê na breve legenda que abre o filme e contextualiza seus acontecimentos como "alguns dias depois do golpe de Estado de 1976"; na blitz feita pelos militares para monitorar as pessoas que circulam pelas ruas de Buenos Aires, inclusive levando um dos motoristas com eles; e no pronunciamento que o presidente Rafael Videla faz na televisão a respeito de aniquilar os rebeldes e fazer a economia crescer. O momento mais contundente é aquele em que a casa no campo do protagonista é invadida, revirada e destruída enquanto ele e sua família estavam fora (não é dito abertamente quem fez aquilo, mas o espectador sabe quem foi).

É interessante pensar como as escolhas estéticas que tornam a ditadura e os agentes da repressão praticamente assombrações não nomeadas que pairam sobre a família do menino. É uma reflexão que se articula ao conceito de contraluz, trabalhado por Márcio Sorelle (2013: 84), que discute como alguns filmes faz eventos sociais traumáticos se desenrolarem na dimensão das entrelinhas, do não dito, do silêncio e do implícito e ainda assim afetarem as trajetórias das personagens. Como o próprio autor aponta, alguns filmes "não encenam diretamente o horror histórico, dando-lhe assim, outras formas de resposta e ressonância" (SORELLE, 2013: 85-86).

A encenação indireta da ditadura ocorre, principalmente, quando as atividades dos pais são sugeridas. A princípio, o pai era advogado e tinha um escritório com seu sócio, já a mãe era cientista e trabalhava em um laboratório. Ambos não permanecem em seus trabalhos, já que o sócio desaparece misteriosamente, o pai deixa o escritório e a mãe diz ter sido demitida. Tais mudanças começam a partir do instante em que a mãe busca o filho mais velho e leva as duas crianças para a casa de amigos, onde se encontram com o pai para seguirem viagem para uma casa afastada. Além de conhecermos pouco sobre o que os adultos fazem, não sabemos seus nomes nem os das crianças.

No máximo temos pistas e detalhes que sugerem a participação dos pais em alguma forma de oposição, embora fique a dúvida se seria uma organização guerrilheira ou outro movimento de resistência à ditadura. As sugestões aparecem nas cenas em que o menino ouve trechos incompletos de diálogos: escuta uma conversa entrecortada sobre 
o desaparecimento do sócio do pai; escuta uma conversa entre o pai e o avô sobre o aumento dos assassinatos cometidos pelos militares; e ouve os pais comentarem de madrugada sobre o cerco policial cada vez maior nos arredores da capital. Em cada momento, a encenação dá destaque ao protagonista no centro da imagem enquanto os diálogos ocorrem no fundo da cena e em voz baixa.

O conceito de contraluz também nos faz perceber que a violência, mesmo não sendo retratada diretamente, afeta as personagens e seu cotidiano. Por conta do autoritarismo e da repressão governamental, as vidas de um menino de dez anos e de seu irmão caçula se transformam completamente: eles mudam de residência; ficam um tempo sem estudar; são matriculados em um colégio religioso onde não conhecem ninguém; deixam para trás seus pertences e amigos. Em especial, o protagonista sofre por ter sido afastado do melhor amigo Bertuccio, não podendo se despedir nem entrar em contato com ele.

A própria estadia da família na nova moradia se altera e cotidiano passa a ter outras regras. Na chegada ao campo, os irmãos são instruídos a atravessar arbustos para se refugiarem em um automóvel escondido quando o pai emitir um sinal de alerta. Os dois são proibidos de atender ou fazer ligações e precisam memorizar a nova história de vida criada como proteção, que incluía novos nomes (o pai se chamaria David, o filho mais velho Harry e o caçula Simon) e novas profissões para os adultos (o pai seria arquiteto e mãe dona de casa). Na essência de tudo isso, os cuidados do casal para proteger a família, como podemos imaginar, das forças repressivas.

Se por um lado a violência do regime não se manifesta explicitamente, por outro lado a narrativa desloca o olhar para sujeitos tradicionalmente menos visibilizados (SORELLE, 2013: 93). No caso específico do filme, não é convencional acompanhar uma trama que se passa no período ditatorial pelo ponto de vista de uma criança, já que os trabalhos de memória se desenvolveram ao longo do tempo priorizando esferas de apoio ou de oposição ao governo. Como um menino de dez anos não participa de disputas políticas, a obra confere contornos particulares ao que Bruno Groppo adverte acerca da amplitude das atitudes sociais durante as ditaduras. O historiador nos lembra que parte da sociedade pode ter colaborado, consentido ou aderido ao regime (GROPPO, 2015: 4243) e Kamchatka indica a existência de tipos de comportamento que ignoravam o cenário político por alguma razão.

E existem muitas estratégias para destacar o cotidiano e a subjetividade de Harry, começando pelo desenvolvimento da narrativa com mentos comuns em família. Estes 
podem ser felizes, como as brincadeiras entre pai e filho, as danças em família, a comemoração do aniversário do avô e a observação das estrelas no céu. Entretanto, podem ser conflituosos porque Harry entra em atrito algumas vezes com os pais ao questionar as obrigações de não usar o telefone e de memorizar as novas identidades. Ainda nesse ponto, a relação que o menino estabelece com o misterioso jovem de codinome Lucas também evoca os traços mais comuns que a vida pode ter. Apesar de ficar implícito que Lucas deve também fazer parte da oposição ao governo, vemos, na verdade, o surgimento de uma amizade após as desconfianças iniciais do menino.

Como o cotidiano da família se desenrola a partir da subjetividade de Harry, a composição das cenas segue essa característica. Na análise de Keyla Andrea S. Oliveira e Pollyanna Rosa Ribeiro, as autoras mostram que os planos alternam entre o ponto de vista objetivo da câmera e o olhar específico do protagonista, de forma a nos fazer acompanhar os acontecimentos de forma parcial (OLIVEIRA; RIBEIRO, 2019: 99). Por exemplo, as brincadeiras com o pai são filmadas com planos gerais que situam o ambiente e as personagens e prosseguem com planos subjetivos que indicam o que o garoto vê no tabuleiro do jogo; e as fotografias retiradas do pai em frente ao mar alternam entre a visão do conjunto da cena e a do garoto pela ótica do equipamento.

Segundo as autoras, fazer a perspectiva de Harry ser a central para a narrativa implica preencher o filme com o afeto, a imaginação e o prazer pelo lúdico típicos da infância (OLIVEIRA; RIBEIRO, 2019: 102). Ao invés de dar sentidos puramente racionais aos novos momentos da vida (algo ainda inviável pelas limitações de uma criança para compreender os significados da imposição de uma ditadura), o menino elabora significados através de sua sensibilidade. Assim, seus dias são movidos pelo carinho em relação à família e a Lucas, pela espontaneidade de quem acredita que se esconder pode ser uma brincadeira e pela criatividade resultante de metáforas compatíveis com sua visão de mundo.

Há metáforas que ultrapassam leituras simplistas e se relacionam com a jornada do protagonista quando três animais surgem em cena. Ao explorar o esconderijo nos arbustos, uma lagarta chama a atenção de Harry como se a delicadeza da natureza superasse os perigos do contexto; ao passar perto da piscina Harry e o irmão se deparam com um sapo que, mais à frente, morre, é enterrado e faz um paralelo com a partida permanente de Lucas; e ao libertar uma pomba presa em uma cerca, David se corta, algo que simbolicamente antecipa os ferimentos emocionais provocados pela separação da família no final da produção (OLIVEIRA; RIBEIRO, 2019: 103-104). 
As alegorias construídas têm em comum o fato de pertencerem ao universo infantil. Isso transparece na abertura, que traz um flashback de um Harry adulto relembrando sua infância e combinando uma aula de Ciências na escola com suas memórias. Ele explica em uma narração em voice over como as espécies evoluem e as células se multiplicam, mas também se questiona se haveria como explicar os mistérios da vida, especialmente o que houve com ele aos dez anos de idade. Mais adiante, a montagem das cenas combina a blitz dos militares com a narração da série de ficção científica que via (de onde o pai escolhe seu codinome e baseada em uma imaginária invasão alienígena a Terra), criando a sensação de que o menino entende os militares como invasores de seu mundo estável.

Mas, acima de tudo, encontrar o livro que conta a trajetória do mundialmente famoso ilusionista Harry Houdini impacta o protagonista. A admiração faz com que o garoto utilize "Harry" como seu codinome e treine para ser como o ídolo, capaz de escapar de cordas que o amarram nas mais desafiadoras situações. Então, seus dias passam a ser a leitura do livro, treinamentos físicos e simulação de fugas de cordas. Em um nível simbólico, Houdini parece a representação do desejo do protagonista de escapar de uma realidade desagradável e retornar para a vida que tinha. Tal como o ilusionista, o jovem quer fugir das amarras que o prendem.

Fugir dessa realidade se relaciona com a sensação de isolamento que carrega. Não pode ver os avós como gostaria (tristeza partilhada pelo pai, que também admite sentir falta dos familiares na triste cena em frente ao mar com a câmera fotográfica); fica decepcionado por ser impedido de se comunicar com o amigo Bertuccio; e se sente frustrado por ver o novo amigo que fez, Lucas, partir permanentemente. Por isso, planeja uma operação de fuga para reencontrar Bertuccio, voltando sozinho para o centro de Buenos Aires. Apesar de ter visto o amigo voltar para casa, a mãe dele mente dizendo que o filho não estava ali. Esta é mais uma decepção para Harry, que vai embora dizendo na narração em voice over que o livro de Houdini nunca contava como o ilusionista escapava.

A mentira que a mãe de Bertuccio conta e a proibição de deixar Harry entrar em sua casa enfatizam o que já havíamos experimentado com os avós da protagonista. Estes personagens coadjuvantes encarnam comportamentos sociais heterogêneos que contrariam memórias capazes de colocar a sociedade em um lugar de resistência à ditadura. Essa mãe evita se envolver com a família de Harry, possivelmente por imaginar o que fariam os pais do garoto e não querer sofrer represálias do governo; já os avós estão 
em uma fase da vida na qual se preocupam com a saúde e com uma rotina confortável alheia à política. Se Bruno Groppo argumenta que precisamos investigar mais a fundo as atitudes que davam apoio e base social ao regime (GROPPO, 2015: 45), o filme encena o distanciamento da política por figuras que sentem medo ou somente vivenciam um cotidiano comum distante dos conflitos políticos.

À medida que a conclusão do filme se aproxima, o cerco da repressão se fecha cada vez mais sobre a oposição. Sentimos isso novamente a partir do olhar limitado e subjetivo de Harry, que observa sem compreender os pais se consolando de madrugada. Os adultos também demonstram sentir muito medo dos riscos após terem a casa invadida e revirada; deixam o local e levam as crianças para restaurantes e parques indecisos do que fazer a seguir; chegam a telefonar para algumas pessoas para conseguir alguma ajuda ou orientação, contudo nunca obtém a resposta esperada como se nota na troca de olhares infelizes de quem não conseguirá manter a família toda reunida e segura. Esgotadas as possibilidades, o casal decide deixar as crianças com os avós e partir de vez para a militância política.

A falta de informações detalhadas para o desfecho combina com o silêncio que se abate após a despedida de Harry e David. A cena se prolonga um pouco mais, sem diálogos, mostrando o menino a observar o carro dos pais se distanciar ao longe. $\mathrm{O}$ silêncio havia sido quebrado apenas alguns minutos antes quando o protagonista conta o que o pai cochichou em seu ouvido: o conselho que esclarece a metáfora em torno do jogo de tabuleiro TEG (Tática e Estratégia de Guerra). Anteriormente, já havíamos visto pai e filho jogando a versão argentina do War, cujo objetivo é derrotar os adversários conquistando certo número de territórios. No único dia em que Harry quase venceu, o pai apenas dominava Kamchatka (uma província na região oriental da Rússia) e a partir desta área impediu a derrota e conseguiu virar o jogo.

Quando combinamos a sequência do jogo à despedida no terceiro ato, o título do filme é justificado. O conselho do pai para Harry é sempre que passar por alguma dificuldade se lembrar de Kamchatka, pois é um lugar de onde se pode resistir. Tal ideia se desdobra em pelo menos três possibilidades, todas elas partindo de alguma situação de isolamento: durante o jogo, o exército de David estava isolado e precisou resistir para vencer; os movimentos de oposição à ditadura, dos quais os pais fazem parte, ficam isolados por conta da clandestinidade a que eram submetidos na luta contra o regime; e o menino se sente isolado e distante dos amigos e dos pais, precisando encontrar forças para resistir às desilusões da vida e de um amadurecimento precoce. 
Seria possível supor que o encerramento da obra destaca a vitimização do protagonista, principalmente por conta da separação de uma família e dos impactos para uma vida tão jovem. No caso dos regimes autoritários e de seus desdobramentos para os períodos democráticos, a nomenclatura vítima pode ser apropriada em contextos que produzem significados perigosos caso sua utilização seja frágil e pouco reflexiva, pois "por meio do culto das vítimas, a sociedade se apresenta ela própria como vítima da ditadura" (GROPPO, 2015: 52). No entanto, Kamchatka não trata Harry como uma simples vítima porque sua jornada dramática envolve o aprendizado de que fugir pode não ser uma solução e resistir pode ser uma conduta necessária. Além disso, o filme não cai na simplificada "teoria dos dois demônios" porque não equipara a violência do Estado e as ações da guerrilha e retrata muito mais uma "zona cinzenta" que não inclui nem a resistência nem o apoio ao regime.

Inicialmente, os historiadores poderiam preferir analisar filmes que retratam temas e períodos históricos de maneira mais explícita. As impressões preliminares poderiam supor que as sutilezas na abordagem do passado ofereceriam pouco material para se examinar e, consequentemente, menos possibilidades de averiguar eventuais representações do passado e narrativas sobre as condições do presente. Entretanto, o cinema não é uma expressão artística que pode construir narrativas sobre temáticas históricas apenas através das informações objetivas que difunde. A dimensão emocional é fundamental, como Robert Rosentone argumenta chamando a atenção que os filmes apresentam discursos detentores de uma importante qualidade vivencial porque "eles fazem isso explorando as grandes potencialidades de sua mídia - dando-nos a ilusão de que, por um curto período, testemunhamos, ou até mesmo vivenciamos, os problemas, iras, medos, alegrias e dores de outras vidas ambientas em outras épocas" (ROSENSTONE, 2010: 223).

Desse modo, na raiz da qualidade vivencial que Kamchatka propõe está o uso da inocência infantil como uma alegoria que fornece uma visão sobre a ditadura civil-militar argentina. Esta inocência se traduz na impossibilidade de Harry compreender tudo que acontece ao seu redor por conta de sua idade e entrelaça experiências individuais a questões políticas mais amplas (LIMA; FERNANDES, 2013: 429). Então, o movimento da narrativa é de um microcosmo em direção a um contexto maior, ou seja, o universo fílmico da família de Harry alcança debates, incertezas, angústias e problemas que afetam toda uma gama de pessoas envolvidas no enfrentamento ao regime, sobretudo os efeitos da repressão para gerar desaparecimentos políticos e desarticulações de famílias. 
Partir de experiências individuais para chegar às experiências históricas também pode ser um movimento que orientou o trabalho do diretor Marcelo Piñeyro, uma criança durante a ditadura civil-militar argentina. Isso porque o realizador experimentou algo semelhante ao que o enredo encena para Harry, tendo na infância convivido brevemente com uma família que estava clandestinidade sem compreender exatamente quem eles eram e o que faziam (LIMA; FERNANDES, 2013: 431). Trata-se de um exemplo sensível de como vivências pessoais podem servir de inspiração para a produção cinematográfica e de historicização de memórias que oferecem ferramentas para pensar o passado ditatorial.

Novas memórias sob a forma de narrativas cinematográficas ou de experiências pessoais são impulsionadas por contextos históricos específicos, que possibilitam aos testemunhos ganharem o espaço público e disputarem o entendimento do passado. Esse cenário é possível devido à reescrita de memórias por novos parâmetros do tempo presente, que envolvem tanto operações de recordação quanto de esquecimento capazes de redefinir identidades individuais E coletivas (GROPPO, 2015: 52). Enquanto os trabalhos de memória se desenvolvem, os cuidados precisam ser mantidos porque nem sempre a explosão de significados para o passado contempla a compreensão das diferentes atitudes sociais durante ditaduras civil-militares.

Portanto, o cinema não pode ser descolado do contexto social, político e econômico no qual se situa. Na passagem dos anos 1990 para os anos 2000, a Argentina vivia a ebulição de um panorama em que a justiça de transição atingia novos episódios e mobilizava mais memórias sobre o passado recente. A atuação de movimentos sociais em defesa dos direitos humanos e de reparação das vítimas, notadamente as Mães e Avós da Praça de Maio, pressionou o governo argentino a corrigir os retrocessos do processo transicional e retomar os julgamentos de agentes da repressão (CAPELATO, 2006: 7475). Enquanto estes fatos tomavam forma e produziam mais memórias, Kamchatka era lançado em 2002 participando de tantos debates a partir do olhar de um protagonista de dez anos.

\section{O passado autoritário pelos olhos infantis}


Kamchatka não é o único filme que aborda alguma ditadura civil-militar latinoamericana pela perspectiva de crianças protagonistas. O Chile assistiu ao lançamento de Machuca em 2004, o Brasil apresentou O Ano em que Meus Pais Saíram de Férias em 2006 e a Argentina também proporcionou Infância Clandestina para o mundo em 2011. Então, de 2002 a 2011, ao menos quatro filmes estabeleceram um retorno às últimas ditaduras em cada país a partir das jornadas de jovens meninos ainda imaturos para compreender o tempo em que viviam. Tomando como exemplo o trabalho de Marcelo Piñeyro, podemos pensar acerca dos efeitos de escolher personagens infantis como centro das narrativas.

Primeiramente, tramas que colocam crianças como protagonistas tendem a despertar rapidamente um vínculo emocional com os espectadores. Em geral, podemos sentir a conexão com nossos passados mais jovens com um toque de nostalgia que nos faz revisitar nossa própria infância. Por outro lado, as crianças parecem mais vulneráveis a diversas ameaças porque ainda não possuem todas as ferramentas para lidar com o mundo. Ainda assim, pode ser reconfortante estar em contato com a ingenuidade e a imaginação de quem mal enxerga os limites das suas ações e de seus desejos.

Com alguma frequência, a presença de jovens está relacionada a um tipo de enredo chamado coming of age. Neste subgênero cinematográfico, crianças ou adolescentes atravessam um processo de amadurecimento que promove sua transformação a partir do desabrochar sexual ou da compreensão de seu lugar no mundo. Como os espectadores já passaram por etapas que levaram a algum tipo de amadurecimento, há mais possibilidades de identificação com a personagem principal. Por exemplo, em Kamchatka, amadurecer significa aceitar o duro fardo de saber que fugir de seus problemas não seria totalmente satisfatório nem quando sua realidade inclui perder o controle de sua vida e se separar forçadamente da família.

E nos filmes acima citados, existe ainda um impacto muito grande para as crianças protagonistas: ter sua inocência perdida precocemente. Em geral, as narrativas são dramas domésticos que tem como centro dramático a família, até o momento em que esta inocência é abalada quando a unidade familiar é rompida abruptamente antes do crescimento deste jovem. Isso acontece de modo a gerar um duplo impacto sobre o espectador em se tratando de Kamchatka: o drama se intensifica por ser um menino de dez anos tendo que lidar com a partida dos pais, que não mais conviverão com ele e seu irmão, e não possuindo arcabouço suficiente para compreender as razões para esta quebra na sua existência. Além disso, mesmo o filme não retratando diretamente a oposição à 
ditadura argentina, o cotidiano de um garoto pode ser afetado e desestabilizado pelo regime autoritário.

No caso da Argentina, há um fator complicador específico que o filme evoca a partir da trajetória de Harry. A ditadura civil-militar argentina, em comparação com os demais governos da América Latina no período, apresentou números ainda mais significativos para a repressão em termos de presos, torturados, assassinados e desaparecidos. Até os dias atuais, a questão não solucionada de muitos desaparecidos reverbera na sociedade argentina, inclusive atingindo o universo infantil já que o sequestro de filhos de guerrilheiros também marcou a repressão ditatorial no país. E no final da produção, esses elementos são evocados simbolicamente ao mostrar Harry separado dos pais e o casal provavelmente engrossando os números de desaparecimentos políticos

Se pensarmos nas possibilidades artísticas de uma obra que tem crianças como protagonistas, podemos também considerar algumas potências de um filme de temática histórica estruturado sob outro olhar. Como já discutimos, a perspectiva infantil carrega consigo uma visão de mundo marcada pela imaginação, pelo afeto e pelo lúdico, que elabora sentidos para o mundo ao seu redor a partir de ferramentas criativas. Harry, por exemplo, utiliza suas referências de um jogo de tabuleiro, de um livro sobre o ilusionista Harry Houdini e de uma série de ficção científica para tentar compreender as mudanças inesperadas em sua vida.

Por conta do olhar criativo das crianças, os filmes constroem suas narrativas também através de metáforas e alegorias criadas por seus aspectos estéticos. Por isso, analisar um filme apenas pelo roteiro à procura dos acontecimentos que se associam à ditadura civil-militar seria uma operação incompleta que não contempla outros elementos da linguagem cinematográfica. Ao construir uma narrativa que representa e reconstrói o passado a partir da montagem, da direção, da trilha sonora e de outros componentes, Kamchatka direciona sua perspectiva não para a resistência feita pelos pais, mas para as experiências emocionais de uma criança. E esta escolha está longe de ser alienante, deixando de abordar questões importantes sobre o passado autoritário.

Uma das questões que podem ser pensadas levando em consideração Kamchatka é a caracterização do cotidiano em tempos autoritários. Seria enganoso pensar que o não envolvimento de indivíduos e grupos sociais nos conflitos políticos da época seria fruto da alienação. Por mais difícil que seja penetrar e examinar o desenrolar do cotidiano, este universo é povoado por pessoas que seguem suas vidas aparentemente sem 
transformações, apesar da suspensão da democracia, porque suas experiências não seriam afetadas a curto prazo pelas tensões políticas. Porém, até uma criança como Harry, que não se envolve em disputas ideológicas, pode ser afetada pelo cenário mais amplo e o dia a dia ser atravessado pela violência daquele contexto.

Outra questão diz respeito aos diversos comportamentos sociais neste período. Ao longo da ditadura, nem todos resistiram ou apoiaram o regime, pois as relações sociais são mais complexas do que divisões maniqueístas. Algumas atitudes podem escapar do maniqueísmo que não compreende o medo de agir politicamente e os silêncios de indivíduos alheios às disputas político-ideológicas. Os avós de Harry, o próprio menino e a mãe de Bertuccio podem simbolizar no filme a diversidade de comportamentos que revelam uma conjuntura incapaz de ser dividida em vítimas e torturadores.

Estas reflexões produzem também memórias que atribuem significados distintos para o passado. Quando se trata da ditadura argentina, as memórias construídas durante o regime, na transição democrática e na atualidade assumem novas formas que possuem sua própria historicidade. Na história do país, já se construíram versões que atribuíram aos militares o papel de salvadores nacionais contra subversão comunista, que associaram a mobilização política das massas e das forças peronistas a uma luta revolucionária e que investem na rememoração dos horrores da repressão para evitar a repetição de novas modalidades de autoritarismo (CAPELATO, 2006: 76).

Como estamos falando de diversos discursos sobre o passado, precisamos considerar as batalhas de memória que se prolongam nos testemunhos ou no cinema. Dentro delas, alguns mitos, maniqueísmos, simplificações e esquecimentos voluntários podem ocorrer por conta de posturas de uma sociedade que evita debates profundos sobre responsabilidades durante a ditadura, tenta ocultar traumas ou aspectos sensíveis do passado, busca reparações jurídicas e simbólicas e confere sentidos aos sofrimentos coletivos. Trata-se de um caldeirão de leituras, representações e memórias de uma mesma época que demanda um trabalho crítico para não disseminar construções problemáticas de um passado que repercute na atualidade.

Logo, uma tarefa importante dos historiadores é construir um conhecimento do passado que chegue ao espaço público e demonstre as potencialidades e limites epistemológicos das memórias. Afinal, os testemunhos não podem ser tomados como únicos meios de acessar este período, assim como podem ainda preservar leituras problemáticas da ditadura na Argentina, como a "teoria dos dois demônios" e os mitos da sociedade vítima inocente e integralmente resistente (GROPPO, 2015: 53). Através de 
um trabalho crítico, percebemos como estas narrativas são prejudiciais por considerar a ditadura um fenômeno imposto apenas pela força, estranho à sociedade, carente de apoio social e desvinculado dos conflitos políticos do período.

Além disso, o cinema pode cumprir uma função importante como produtor de representações do passado que contribuem para debates históricos. Em Kamchatka, a encenação da ditadura pode ser sutil nos silêncios e nas sugestões de cada cena, mas nem por isso seria menos interessante para a reflexão. A partir dos sinais dados pelos pais (o medo da mãe em uma blitz militar procurando documentos falsos e a indignação do pai com o discurso na televisão do presidente Videla a respeito de um projeto econômico gerador de mais miséria) e das reviravoltas na vida de Harry, o filme mostra os impactos devastadores que a ditadura acarreta para uma sociedade.

Além de trazer sua visão histórica particular, Kamchatka também se insere nas disputas e discussões de seu tempo. A produção faz parte de um contexto de multiplicação de narrativas sobre a ditadura civil-militar argentina, tendo ela própria seu trabalho de construção de memórias. O protagonismo de uma criança ressignifica as noções possíveis para o conceito de resistência. O olhar infantil igualmente simboliza a variedade de experiências e memórias que o período entre os anos 1990 e 2000 trouxe à tona, podendo vir das lutas de movimentos sociais em busca de verdade e justiça ou do trabalho estético de um diretor de cinema que vivenciou na sua infância um regime ditatorial.

Com o diálogo que propusemos entre as reflexões de Bruno Groppo e o filme Kamchatka, buscamos oferecer interpretações possíveis para o cotidiano e para diferentes comportamentos sociais em tempos de regimes de exceção. Assim como o Brasil, a Argentina também enfrenta disputas de memória referentes à ditadura civil-militar e aos desdobramentos anos depois. Diferentemente do Brasil, a Argentina vem tendo experiências mais sólidas de enfrentamento da violência política e das heranças autoritárias daquele Estado, como fica patente na comparação entre os governos Fernández e Bolsonaro. Então, a história comparada entre os dois países e as relações entre cinema e história têm em comum o fato de olharem para o passado e atuarem sobre o presente.

\section{Fontes}

PIÑEYRO, Marcelo (dir.) (2002). Kamchatka (Argentina). Patagonik Film Group. 105 $\min$. 


\section{Referências bibliográficas}

CAPELATO, Maria Helena (2006). Memória da ditadura militar argentina: um desafio para a história. Clio - Revista de pesquisa histórica, n. 24.

CAPELATO, Maria Helena et al. (2007). História e cinema. São Paulo: Alameda.

CHARTIER, Roger (2006). A visão do historiador modernista. In: FERREIRA, Marieta de Moraes; AMADA, Janaína (orgs.). In: Usos e abusos da história oral. Rio de Janeiro: Editora FGV.

GROPPO, Bruno (2015). O mito da sociedade como vítima: as sociedades pós-ditatoriais em face de seu passado na Europa e na América Latina. In: ROLLEMBER, Denise; QUADRAT, Samantha Viz. História e memória das ditaduras do século XX, vol. 1. Rio de Janeiro: Editora FGV.

LIMA, Fernanda Luiza Teixeira; FERNANDES, Luiz Estevam de Oliveira (2013). Pelos olhos de uma criança: as ditaduras militares latinoamericanas no cinema contemporâneo. Anos 90, Porto Alegre, v. 20, n. 38, dez.

OLIVEIRA, Keyla Andrea Santiago; RIBEIRO, Pollyanna Rosa (2019). O protagonismo infantil por meio da resistência em Kamchatka (2003). Colloquium Humanarum, Presidente Prudente, v. 16, n. 4, out./dez.

PASSERINI, Luisa (2006). A "lacuna" do presente. In: FERREIRA, Marieta de Moraes; AMADA, Janaína (orgs.). In: Usos e abusos da história oral. Rio de Janeiro: Editora FGV.

RÉMOND, René (2006). Algumas questões de alcance geral à guisa de introdução. In: FERREIRA, Marieta de Moraes; AMADA, Janaína (orgs.). In: Usos e abusos da história oral. Rio de Janeiro: Editora FGV.

ROSENSTONE, Robert A. (2010). A história nos filmes, os filmes na história. Tradução de Marcello Lino. São Paulo: Paz e Terra.

SERELLE, Márcio (2014). Cinema e contraluz: limiares da repressão na cultura midiática argentina. Galaxia, São Paulo, n. 28, dez.

Artigo recebido em 15 de agosto de 2021.

Aprovado em 07 de dezembro de 2021.

DOI: 10.12957/intellectus.2021.61695 